\title{
Phytochemicals Screening, GC/MS Characterization, and Antioxidant Activity of Falcataria moluccana Miq. Barneby and J. W. Grimes Methanolic Extract
}

\author{
Alfi Rumidatul*, I Nyoman Pugeg Aryantha, Endah Sulistyawati
}

Alfi Rumidatul*, I Nyoman Pugeg Aryantha, Endah Sulistyawati

School of Life Sciences and Technology, Institut Teknologi Bandung, Jalan Ganesha 10 Bandung 40132, West Java, INDONESIA.

\section{Correspondence}

\section{Alfi Rumidatul}

School of Life Sciences and Technology, Institut Teknologi Bandung, Jalan

Ganesha 10 Bandung 40132, West Java, INDONESIA.

E-mail: alfi@sith.itb. ac.id

History

- Submission Date: 04-11-2020;

- Review completed: 27-11-2020;

- Accepted Date: 04-12-2020

DOI : 10.5530/pj.2021.13.57

Article Available online

http://www.phcogj.com/v13/i2

\section{Copyright}

(C) 2021 Phcogj.Com. This is an openaccess article distributed under the terms of the Creative Commons Attribution 4.0 International license.

\begin{abstract}
Introduction: In this study, Falcataria moluccana as a plant of West Java community forest was evaluated for its phytochemical content, characterization of secondary metabolites through GC/MS analysis, and antioxidant activity with the DPPH method. Methods: The extraction of F. moluccana twig used maceration with methanol solvent. Phytochemical compounds in $F$. moluccana methanolic extract were identified using Gas Chromatography-Mass Spectrometry (GC/MS). The antioxidant activity was tested against 2,2-diphenyl1- picrylhydrazyl (DPPH). Results: The phytochemical screening of $F$ moluccana methanolic extract showed the presence of phenolics, flavonoids, steroids, terpenoids, saponins, and tannins. The results of GC/MS analysis showed that the highest abundance was $\alpha$-terpinolenic from the terpenoid group with a retention time of 6.776 minutes and a percentage area of $25.85 \%$. Total phenolic content in methanolic extract of F. moluccana was $145.21 \mathrm{mg}$ GAE/g, total flavonoid was $95.39 \mathrm{mg}$ QE/g while antioxidant activity (IC50) was $12.60 \mathrm{ppm}$. Conclusion: F. moluccana has potential as natural antioxidant and its active compounds can be developed as pharmaceutical raw materials.
\end{abstract}

Key words: Falcataria moluccana, Phytochemical, GC/MS, Antioxidant, Methanolic extract.

\section{INTRODUCTION}

Plants are very rich in secondary metabolite components with specific bioactivity for human needs in the health sector. The factor determining the pharmacological activity of plants is the content of secondary metabolites. Isolated secondary metabolites from plants have interesting bioactivity. Several studies found that secondary plant metabolites have bioactivity as antidiabetic ${ }^{1}$, anti-inflammatory ${ }^{2}$, antimicrobial ${ }^{3}$, anticancer ${ }^{4}$, anthelmintic $^{5}$, and antioxidants. ${ }^{6}$

Antioxidants can be produced both synthetically and naturally, but synthetic antioxidants have a toxic effect compared to natural antioxidants. ${ }^{7}$ Natural antioxidants can be sourced from plants containing bioactive compounds in the form of secondary metabolites such as alkaloids, flavonoids, steroids, terpenoids, and others. Currently, a lot of biological and pharmaceutical exploration is carried out on plants. This is based on the fact that plants contain antioxidants and other bioactive components. Therefore, studies to replace synthetic antioxidants with natural antioxidants are necessary.

One of the potential plants as a source of natural antioxidant compounds is $F$. moluccana which is a multipurpose species in Southeast Asian plantations, especially Indonesia and Malaysia. ${ }^{8}$ The purpose of this study was to find out phytochemical content, characterization of secondary metabolites by GC/MS analysis, and antioxidant activity of $F$. moluccana methanolic extract.

\section{MATERIAL AND METHODS}

\section{Materials}

F. moluccana twig were obtained from sengon plantation in Cisempur Village, Jatinangor SubDistrict, Sumedang Regency, West Java, Indonesia. All chemical reagents for phytochemical screening i.e. methanol, folin-ciocalteau, phenol, ammonia, toluene, chloroform, hydrochloric acid, dragendorff reagent, mayer reagent were purchased from Merck. Gallic acid, quercetin, 2,2-diphenyl-1-picrylhydrazyl $(\mathrm{DPPH})$ were purchased from Sigma-Aldrich (MO, USA).

\section{Extraction}

The extraction of $F$. moluccana twig was carried out with a maceration technique using a methanol solvent. ${ }^{9}$ Dried branches were crushed to a powder. $50 \mathrm{~g}$ of simplicia was macerated using $200 \mathrm{~mL}$ of methanol for 72 hours while shaking it in a shaker. Then, the solution was filtered using Whatman No. 42 filter paper. Then, the filtrate was evaporated using a rotary evaporator until obtaining a concentrated extract.

\section{Phytochemical screening}

The phytochemical test aims to find out the content of secondary metabolites in a plant-based on reactions that produce color or deposits. In this study, the test for alkaloids, steroids, triterpenoids, phenolics, flavonoids, saponins, and tannins was carried out. ${ }^{10}$ 


\section{Alkaloids}

$50 \mathrm{mg}$ was added to $5 \mathrm{~mL}$ of chloroform and 3 drops of ammonia. The chloroform fraction was separated, then 45 drops of $2 \mathrm{M} \mathrm{H}_{2} \mathrm{SO}_{4}$ were added. The acid fraction (above) was taken and Dragendorf, Mayer, and Wagner reagents were added. The positive result was characterized by the formation of red deposit on the addition of Dragendorf reagent, white deposit in Meyer reagent, and brown deposit in Wagner reagent.

\section{Steroid and terpenoid}

$5 \mathrm{mg}$ of extract was added to $5 \mathrm{~mL}$ of hot ethanol. The solution was filtered and evaporated until dry. Then, $1 \mathrm{~mL}$ of diethyl ether was added and homogenized. A drop of concentrated $\mathrm{H}_{2} \mathrm{SO}_{4}$ and anhydrous acetic acid were added to the solution. Green or blue color indicated steroid content, while red or purple color indicated terpenoid content.

\section{Phenolic}

$5 \mathrm{mg}$ of sample was dissolved in $2 \mathrm{~mL}$ of methanol. The solution was filtered then the filtrate was mixed with $10 \% \mathrm{NaOH}$ then heated. The red color indicated phenolic compounds.

\section{Flavonoid}

$5 \mathrm{mg}$ of the extract was mixed into $5 \mathrm{~mL}$ of distilled water, then heated at $80{ }^{\circ} \mathrm{C}$ for 5 minutes. The solution was filtered and added with magnesium powder, $\mathrm{HCl}$ : ethanol (1: 1) solution, and amyl alcohol. The red or orange color of the amyl alcohol layer indicated flavonoids.

\section{Saponins}

$5 \mathrm{mg}$ of saponin extract was added to $5 \mathrm{~mL}$ of distilled water, then heated at $80^{\circ} \mathrm{C}$ for 5 minutes. The solution was filtered and shaken vigorously until foamy. The positive result was indicated by steady foam for 15 minutes.

\section{Tannins}

$5 \mathrm{mg}$ of extract was added to $5 \mathrm{~mL}$ of distilled water, then heated at 80 ${ }^{\circ} \mathrm{C}$ for 5 minutes. The solution was filtered and added with 3 drops of $10 \% \mathrm{FeCl}_{3}$. Dark blue or greenish-black color indicated tannins.

\section{Gas Chromatography/Mass Spectrometry (GC/MS) Analysis}

The F. moluccana methanolic extract was analyzed using GC/MS Shimadzu QP 2010 (Shimadzu Corp., Kyoto, Japan), RTx5MS (Restek Corp.) columns of $30 \mathrm{~m}$ length, $250^{\circ} \mathrm{C}$ injectors and detectors, and 50 $300{ }^{\circ} \mathrm{C}$ operating temperature. The temperature rise at $50-120^{\circ} \mathrm{C}$ was regulated with a temperature rise rate of $40{ }^{\circ} \mathrm{C} /$ minute and held for 1 minute then a temperature increase of $120-300{ }^{\circ} \mathrm{C}$ was adjusted with a temperature rise rate of $60{ }^{\circ} \mathrm{C} /$ minute and held for 5 minutes in total retention time (Rt) of 60 minutes. The carrier gas was helium with a molecular weight range of 50-500. The compound was identified by the Wiley/NIST Library software. ${ }^{11}$

\section{Total phenolic content}

The total phenolic content was calculated to determine the amount of phenol in the sample. The extract solution was produced at a concentration of $100 \mathrm{mg} / \mathrm{L}$ in the form of the extract dissolved in absolute methanol. After that, $0.2 \mathrm{~mL}$ of the extract was added with $2.5 \mathrm{~mL}$ of $10 \%$ Folin Ciocalteu reagent dissolved in water, then added with $2 \mathrm{~mL} 7.5 \% \mathrm{Na}_{2} \mathrm{CO}_{3}$. The sample was left in a water bath at $45{ }^{\circ} \mathrm{C}$ for 45 minutes. This procedure was carried out three times and the absorbance measurement was carried out at a wavelength of $765 \mathrm{~nm}$. Gallic acid was used as standard with concentrations of 10, 20, 30, 40, and $50 \mathrm{ppm}$. The total phenolic content was expressed as GAE = Gallic Acid Equivalent milligrams per gram of extract. ${ }^{12}$

\section{Total flavonoid content}

The total flavonoid content was calculated using the colorimetric method. The extract solution was produced at a concentration of 500 $\mathrm{mg} / \mathrm{L}$ in the form of the extract dissolved in methanol, then $5 \mathrm{~mL}$ extract was added with $0.3 \mathrm{~mL} 5 \% \mathrm{NaNO}_{2}$. Then, it was added with $0.3 \mathrm{~mL} 10 \%$ $\mathrm{AlCl}_{3}$, dissolved with methanol, and rested at room temperature for 5 minutes. Then, it was added with $2 \mathrm{~mL} 1 \mathrm{M} \mathrm{NaOH}$ and the solution volume was added up to $10 \mathrm{~mL}$ with distilled water. The absorbance was measured with a UV-Visible spectrophotometer at a wavelength of 510 $\mathrm{nm}$. The standard used was quercetin with a concentration of 10,20 , 30,40 , and $50 \mathrm{ppm}$. The flavonoid content was expressed by Quercetin Equivalent (QE) mg per gram of dry extract (Quercetin Equivalent (QE) $\mathrm{mg} / \mathrm{g}$ extract). ${ }^{13}$

\section{Antioxidant activity}

$1 \mathrm{~mL}$ of $F$. moluccana methanolic extract with $100,200,300,400$, and $500 \mathrm{ppm}$ concentrations were mixed with $2 \mathrm{~mL}$ of $0.002 \% \mathrm{DPPH}$ solution and rested for 30 minutes. The absorbance was measured at a wavelength of $517 \mathrm{~nm}$. The positive control used ascorbic acid $(5,10,15$, 20 , and $25 \mathrm{ppm}$ concentrations). The inhibitory power was calculated using the following formula:

Inhibitory power $(\%)=$ Blank absorbance - Sample Absorbance $\mathrm{x} 100 \%$

\section{Blank absorbance}

$\mathrm{IC}_{50}$ (inhibitory concentration) was determined by calculating the concentration with 50\% inhibition from linear regression equation.

\section{RESULTS AND DISCUSSION}

\section{Phytochemical Screening of F. moluccana Methanolic Extract}

Phytochemical screening was carried out to test the alkaloids, flavonoids, saponins, tannins, steroids, terpenoids, and phenolics. The phytochemical components of $F$. moluccana methanolic extract can be seen in Table 1. The results of phytochemical testing showed that the F. moluccana methanolic extract had flavonoids, steroids, terpenoids, phenolics, saponins, and tannins, except alkaloid.

Phenolic and flavonoid compounds showed high antioxidant activity. Flavonoids have the ability to be antiviral, antibacterial, anti-tumor, anti-allergic, anti-inflammatory, and anti-carcinogen. ${ }^{15}$ Several studies found that secondary metabolites from plants that have many roles as antioxidants and antibacterials are phenolic compounds in the form of flavonoids. ${ }^{16}$

F. moluccana methanolic extract contains active compounds in the form of steroids and terpenoids. Steroid and terpenoid compounds have a carbon structure derived from six isoprene units and are biosynthetically derived from acyclic C30 hydrocarbons such as squalene. Squalene is a natural antioxidant, classified as triterpene compounds, and intermediates in plant and animal sterol biosynthesis. Steroids are natural antioxidant as an anti-radical and antioxidant. ${ }^{17}$

\section{Table 1: Phytochemical Screening of $\boldsymbol{F}$. moluccana Methanolic Extract.}

\begin{tabular}{cccc}
\hline No & Chemical Component & Reagent & Results \\
\hline 1. & Alkaloids & Dragendorff & - \\
& & Wagner & - \\
& & Mayer & - \\
2. & Flavonoids & $\mathrm{HCl}, \mathrm{Mg}$ powder, amyl alcohol & + \\
3. & Terpenoids/Steroids & Liebermann-Burchard & + \\
4. & Phenolic & Methanol and $10 \% \mathrm{NaOH}$ & + \\
5. & Saponins & Hot water and shaken & + \\
6. & Tanins & $10 \% \mathrm{FeCl}_{3}$ & + \\
\hline
\end{tabular}

Note: $+=$ positive compound, $-=$ negative compound 
F. moluccana methanolic extract contains saponin and tannin compounds. Saponins are known as foam substances and are generally used as antioxidants, anticancer, and anti-inflammatory. Tannins are phenolic compounds used therapeutically as antimicrobial, antiinflammatory, anti-diarrheal, hemostatic, and anti-hemorrhoidal. ${ }^{18}$ Secondary metabolites are a very important component in biological activity related to pharmacology.

\section{GC/MS analysis}

The results of GC/MS analysis showed that 20 compounds were identified in F. moluccana methanolic extract. This analysis showed that the highest abundance was $a$-terpinolenic from the terpenoid group with a retention time of 6.776 minutes and a percentage area of $25.85 \%$. a-terpinolene is a terpenoid group (monoterpenes) with a molecular formula of $\mathrm{C}_{10} \mathrm{H}_{16}$ and a molecular weight of $136.24 \mathrm{~g} /$ mol which functions as a food additive or flavoring agent. ${ }^{19}$ The $F$. moluccana methanolic extract contains different types of triterpene such as $\alpha$-pinen, $\alpha$-terpinolene, $\alpha$-terpineol, and dl-limonene.

Several compounds have antioxidant and antimicrobial activities such as a-pinene, limonene, camphene, eucalyptol or 1,8-cineol, tetradecanoic acid, hexadecanoic acid/palmitic acid. ${ }^{20-22}$ Miguel $^{23}$ found a 1,8-cineol compound in the leaves and stems of Myrtus communis with good antioxidant activity but still lower than Butyl Hydroxy Anisol (BHA) and Butyl Hydroxy Toluene (BHT). Rowe ${ }^{24}$ reported that Butylated Hydroxy Toluene (BHT) is used as an antioxidant in cosmetics, food, and medicine. Manuja et. $a l^{25}$ stated that benzoic acid has important bioactivities such as antimicrobial, antioxidant, antimutagenic, antiestrogenic, and anti-inflammatory.

\section{Total phenolic content of F. moluccana methanolic extract}

The total phenolic content was calculated with the Folin-Ciocalteau reagent to form a complex solution with phenolic compounds. The total phenolic content was expressed by gallic acid equivalent milligrams per gram of extract. This study used gallic acid as a standard. This study used gallic acid with 10,20,30, 40, and $50 \mathrm{ppm}$ concentrations. The standard curve of gallic acid had linear regression with $\mathrm{y}=0.046 \mathrm{x}+0.647$ and $\mathrm{R}^{2}$ $=0.963$. Based on the results, the total phenolic content of F. moluccana methanolic extract was $145.21 \mathrm{mg}$ GAE/g. The total phenolic content of F. moluccana methanolic extract was higher than the total phenolic content of Averrhoa bilimbi (79 mg GAE/g) methanolic extract ${ }^{26}$ and Moringa oliefera (44.03 mg GAE/g) methanolic extract. ${ }^{27}$

Phenolic compounds are known to have beneficial antioxidant activity for the body as an antidote to free radicals. Phenolic compounds reduce free radicals by binding to metal ions and inhibiting enzymatic systems that play a role in the formation of free radicals such as cyclo-oxygenase, mono-oxygenase, or xanthine oxidase. The antioxidant effect on phenolic compounds is due to the ability to reduce and allow phenolic compounds to have free radical scavenging activity mechanisms, metal chelating intermediate activity, and singlet oxygen-reducing activity. In addition, phenolic compounds play an important role in stabilizing lipid peroxidases and inhibiting the oxidation of various enzymes. ${ }^{28}$

\section{Total flavonoid content of $F$. moluccana methanolic extract}

The total flavonoid content of F. moluccana methanolic extract was calculated by using the $\mathrm{AlCl}_{3}$ staining method which can be seen from the complex formation between $\mathrm{AlCl}_{3}$ and the keto group. The total flavonoid content of $F$. moluccana methanolic extract was calculated with a standard quercetin curve, namely $\mathrm{y}=0.134 \mathrm{x}-0.3$ with $\mathrm{R}^{2}=$ 0.945. The total flavonoid content was determined by substituting the absorbance values into the standard curve equation. Flavonoid content was expressed by Quercetin Equivalent (QE) mg per gram of dry extract. Based on the results, the total flavonoid content of $F$. moluccana methanolic extract was $95.39 \mathrm{mg} \mathrm{QE} / \mathrm{g}$. The total flavonoid content of F. moluccana methanolic extract was higher than the total flavonoid content of Averrhoa bilimbi (15 mg GAE/g) ethanolic extract ${ }^{26}$ and Moringa oliefera (28.33 mg GAE/g) methanolic extract. ${ }^{27}$

Flavonoids are polyphenolic compounds in plants. Flavonoids are divided into six subgroups, namely flavones, flavanols, flavanones, isoflavones, and anthocyanins. Flavonoids can prevent cancer and have an important effect on cancer chemoprevention and chemotherapy. There are many mechanisms of flavonoids including carcinogen inactivation, antiproliferation, cell cycle arrest, induction of apoptosis and differentiation, inhibition of angiogenesis, antioxidants, and a

Table 2: GC/MS Analysis of F. moluccana Methanolic Extract.

\begin{tabular}{|c|c|c|c|c|}
\hline Names of Components & $\begin{array}{l}\text { Retention Time } \\
(\mathrm{mim})\end{array}$ & Molecular Formula & $\begin{array}{c}\text { Molecular Weight } \\
(\mathrm{g} / \mathrm{mol})\end{array}$ & Peak Area (\%) \\
\hline 1. $a$-pinene & 4.564 & $\mathrm{C}_{10} \mathrm{H}_{16}$ & 136.23 & 8.91 \\
\hline 2. Camphene & 4.784 & $\mathrm{C}_{10} \mathrm{H}_{16}$ & 136.23 & 4.82 \\
\hline 3. 1-Phellandrene & 5.537 & $\mathrm{C}_{10} \mathrm{H}_{16}$ & 136.23 & 0.63 \\
\hline 4. Delta 3-Carene & 5.632 & $\mathrm{C}_{10} \mathrm{H}_{16}$ & 136.23 & 10.66 \\
\hline 5. Bicyclo[4.1.0]hept-2-ene, 3,7,7-trimethyl- & 5.710 & $\mathrm{C}_{13} \mathrm{H}_{20}$ & 176.3 & 12.00 \\
\hline 6. Benzene, methyl(1-methylethyl)- (CAS) Cymol & 5.827 & $\mathrm{C}_{10} \mathrm{H}_{14}$ & 134.22 & 2.47 \\
\hline 7. dl-Limonene & 5.892 & $\mathrm{C}_{10} \mathrm{H}_{16}$ & 136.23 & 12.13 \\
\hline 8. Eucalyptol & 5.960 & $\mathrm{C}_{10} \mathrm{H}_{18} \mathrm{O}$ & 154,25 & 2.98 \\
\hline 9. $\gamma$-Terpinene & 6.327 & $\mathrm{C}_{10} \mathrm{H}_{16}$ & 136.23 & 7.38 \\
\hline 10. a-Terpinolene & 6.776 & $\mathrm{C}_{10} \mathrm{H}_{16}$ & 136.23 & 25.85 \\
\hline 11. Azulene (CAS) Cyclopentacycloheptene & 8.267 & $\mathrm{C}_{10} \mathrm{H}_{8}$ & 128.17 & 1.61 \\
\hline 12. $a$-Terpineol & 8.303 & $\mathrm{C}_{10} \mathrm{H}_{18} \mathrm{O}$ & 154,25 & 2.06 \\
\hline 13. 1-Dodecanol (CAS) n-Dodecanol & 12.020 & $\mathrm{C}_{12} \mathrm{H}_{26} \mathrm{O}$ & 186.34 & 1.89 \\
\hline 14. Butyl Hydroxy Toluene & 12.598 & $\mathrm{C}_{15} \mathrm{H}_{24} \mathrm{O}$ & 220,35 & 1.25 \\
\hline 15. Octadecane (CAS) n-Octadecane & 13.507 & $\mathrm{C}_{18} \mathrm{H}_{38}$ & 254.5 & 1.32 \\
\hline 16. Dodecyl trifluoroacetate & 14.424 & $\mathrm{C}_{14} \mathrm{H}_{25} \mathrm{~F}_{3} \mathrm{O}_{2}$ & 282.34 & 0.67 \\
\hline 17. Oxalic acid, cyclohexylmethyl tridecyl ester & 14.830 & $\mathrm{C}_{22} \mathrm{H}_{40} \mathrm{O}_{4}$ & 368.5 & 0.86 \\
\hline 18. Tetradecanoic acid, methyl ester (CAS) Methyl myristate & 14.944 & $\mathrm{C}_{15} \mathrm{H}_{30} \mathrm{O}_{2}$ & 242.4 & 1.24 \\
\hline 19. 9-Heptadecanone & 16.535 & $\mathrm{C}_{17} \mathrm{H}_{34} \mathrm{O}$ & 254.5 & 0.59 \\
\hline 20. Hexadecanoic acid (CAS) Palmitic acid & 17.374 & $\mathrm{C}_{16} \mathrm{H}_{32} \mathrm{O}_{2}$ & 256.42 & 0.67 \\
\hline
\end{tabular}


Table 3: Antioxidant Activity of F. moluccana Methanolic Extract.

\begin{tabular}{cccc}
\hline Extract & Concentration $(\mathrm{ppm})$ & \% Inhibition & $\mathrm{IC}_{50}(\mathrm{ppm})$ \\
\hline & 100 & 58.24 & 62.90 \\
& 200 & 70.75 & 75.04 \\
\\
F. moluccana methanolic extract & 300 & 89.04 & 12.6 \\
Ascorbic acid & 400 & 14.22 & 21.22 \\
& 500 & 48.24 & 2.17 \\
\end{tabular}

combination of these mechanisms. Flavonoids can be good anticancer agents. ${ }^{29}$

\section{Antioxidant activity of $F$. moluccana methanolic extract}

Antioxidant activity test was carried out with the DPPH (1,1-diphenyl2-picrylhydrazil) method based on the ability of antioxidants to donate protons to DPPH radicals. This method is often used to test antioxidant activity because of its direct, simple, and fast measurement of inhibition. DPPH solution was mixed with a substance that can donate hydrogen atoms, so there would be a change in the color of DPPH from purple to yellow. ${ }^{30}$ DPPH radical inhibition of $F$. moluccana methanolic extract produces an Inhibitory Concentration value of 50 $\left(\mathrm{IC}_{50}\right)$ or a concentration of antioxidants that can inhibit free radicals by $50 \%$. The $\mathrm{IC}_{50}$ value was obtained through a linear regression equation of inhibition percentage and sample concentration. The lower the $\mathrm{IC}_{50}$ value, the higher the inhibition of the extract against free radicals. The classification of antioxidant activity is based on the $\mathrm{IC}_{50}$ value, namely very strong antioxidants $\left(\mathrm{IC}_{50}<50 \mathrm{ppm}\right)$, strong antioxidants $\left(\mathrm{IC}_{50}=\right.$ 50-100 ppm), moderate antioxidants $\left(\mathrm{IC}_{50}=101-150 \mathrm{ppm}\right)$, and weak antioxidants $\left(\mathrm{IC}_{50}>150 \mathrm{ppm}\right){ }^{31}$ This study used ascorbic acid as a standard measure of antioxidant activity.

The antioxidant activity of $F$. moluccana methanolic extract and ascorbic acid as positive control can be seen in Table 3 . IC $\mathrm{I}_{50}$ of $F$. moluccana methanolic extract was $12.6 \mathrm{ppm}$ (below $50 \mathrm{ppm}$ ) so that the secondary metabolite of $F$. moluccana methanolic extract can be expressed as a very strong antioxidant. ${ }^{31} \mathrm{IC}_{50}$ of ascorbic acid was 2.17 $\mathrm{ppm}$. The antioxidant activity of $F$. moluccana methanolic extract was lower when compared with ascorbic acid as positive control. Ascorbic acid is easily oxidized by donating hydrogen atoms and forms relatively stable ascorbyl free radicals.

$\mathrm{IC}_{50}$ value of $F$. moluccana methanolic extract was lower than $\mathrm{IC}_{50}$ of Averrhoa bilimbi (4.27 ppm) methanolic extract. ${ }^{27}$ The high antioxidant activity of $F$. moluccana methanolic extract is related to the content of compounds in the extract that play an important role in antioxidant activity. The results of phytochemical screening showed that $F$. moluccana methanolic extract has phenols, steroids, terpenoids, flavonoids, saponins, and tannins. The results of GC/MS analysis showed the methanolic extract of $F$. moluccana branches which affect radical inhibiting properties such as phenols and triterpenes.

\section{CONCLUSION}

The phytochemical screening of F. moluccana methanolic extract showed the presence of phenolics, flavonoids, steroids, terpenoids, saponins, and tannins. The results of GC/MS analysis showed the presence of compounds with antioxidant activity. F. moluccana methanolic extract had a very strong antioxidant activity with an $\mathrm{IC}_{50}$ value was $12.6 \mathrm{ppm}$. F. moluccana methanolic extract has the potential as a source of bioactive antioxidant compounds.

\section{ACKNOWLEDGMENTS}

The author would like to thank Research of Higher Education, Ministry of Research Technology and Higher Education Republic of Indonesia, for providing Research Grant No. 127/SP2H/PTNBH/DRPM/2018 for this research.

\section{REFERENCES}

1. Ahmed QU, Dogaral BBS, Amiroudine MZAM, Taher M, Latip J and Muhammad BY. Antidiabetic activity of the leaves of Tetracera indica Merr. (Dilleniaceae) in vivo and in vitro. Journal of Medicinal Plants Research. 2012;6(49):5912-22

2. Sirsat DM, Bhale PS, Chavan HV, Karape SM and Bachute MT. Synthesis and Anti-microbial, Aanti-oxidant and Anti-inflammatory Activities of Thiazolepyrazole Based Pyrimidine Derivates. Rasayan J. Chem. 2020;13(3):1589-97.

3. Juwitaningsih T, Jahro IS, Dumariris I, Hermawati E, and Rukayadi Y Phytochemical, Antibacterial, Antioxidant and Anticancer Activity Study of $M$ candidum Leaf Acetone Extract. Rasayan J. Chem. 2020;13(2):1096-1103.

4. Xiao Z, Morris-Natschke SL, and Lee KH. Strategies for the Optimization of Natural Leads to Anticancer Drugs or Drug Candidates. Medicinal Research Reviews. 2015;36(1):32-91

5. Balqis U, Muslina M, Hambal M, Athaillah F, Muttaqien M, Azhar A, Ismail I, Rastina R, Eliawardani E, Harris A, Hamzah A, Vanda $H$, and Darmawi D. Histopathological Changes of Egg Cells in the Uterine of Ascaridia galli after Treatment with Extract of Veitchia merrillii Nuts. Traditional Medicine Journal. 2017;22(3):139-45

6. Haro G, Iksen I, Rumanti RM, Marbun N, Sari RP, Gultom RPJ. Evaluation of antioxidant activity and minerals value from watercress (Nasturtium officinale R.Br.). Rasayan J. Chem. 2018;11(1):232-37.

7. Al-Faqeeh LAS, Naser R, and Kagne SR. Phytochemical screening and antioxidant activity of Hypsizygus ulmarius (Bull.). Research J. Pharm. and Tech. 2020;13(9):4297-4302

8. Rahayu S, See L, Shukor NAA, and Saleh G. Environmental factors related to gall rust disease development on Falcataria moluccana (Miq.) Barneby \& J.W. Grimes Atbrumas Estate, Tawau, Sabah, Malaysia. Applied Ecology And Environmental Research. 2018;16(6):7485-99.

9. Insanu M, Aziz S, Fidrianny I, Hartati R, Elfahmi, Sukrasno and Wirasutisna KR. Natural anthraquinonefrom the bark of Cinchona officinalis L. Rasayan J. Chem. 2019:12(2):519-22.

10. Mutuku CS, Thangiah AS, and Obey JK. Phytochemical screening and antimicrobial evaluation of ethanolic-aqua extract of Stachytarpheta jamaicensis (L.) vahl leaves against some selected human pathogenic bacteria. Int. J. Bioassays. 2019;12(1):300-7.

11. Irawan C, Foliatini, Hanafi, Sulistiawaty L, and Sukiman M. Volatile Compound Analysis using GC-MS, Phytochemical Screening and Antioxidant Activities of the Husk of "Julang-Jaling" (Archidendron bubalinum (Jack) I.C Nielsen) from Lampung, Indonesia. Pharmacogn J. 2018;10(1):92-8.

12. Wang J, Wang R, Xiao Q, Liu C, Deng F, and Zhou H. SPME/GC-MS characterization of volatile compounds of Chinese traditional-chopped pepper during fermentation. International Journal of Food Properties. 2019;22(1):86372 .

13. Mtunzi FM, Ejidike IP, Matamela T, Dikio ED, Klink MJ. Phytochemical Profiling Antioxidant and Antibacterial Activities of Leaf Extracts from Rhus leptodictya. International Journal of Pharmacognosy and Phytochemical Research. 2017;9(8):1090-99. 
14. Soltanzadeh H, Acik L, Turk M, Houshmand M, Shahsavari G. Antimicrobial, antioxidant, cytotoxic and apoptotic activities of Satureja khuzestanica. Gazi Medical Journal. 2018;29(3):264-70

15. Mtunzi FM, Ejidike IP, Ledwaba I, Ahmed A, Pakade VE, Klink MJ, Modise SJ. Solvent-solvent fractionations of Combretum erythrophyllum (Burch.) leave extract: Studies of their antibacterial, antifungal, antioxidant and cytotoxicity potentials. Asian Pacific Journal of Tropical Medicine. 2017;10(7):670-79.

16. Bazaka K, Jacob M, Chrzanowski W, Ostrikov K. Anti-bacterial surfaces: natura agents, mechanisms of action, and plasma surface modification. Rsc Advances. 2015;5(60):48739-59.

17. Amarowicz R. Squalene: A natural antioxidant?. European Journal Lipid Science Technology, 2009;111(5):411-12.

18. M. Sermakkani and V. Thangapandian. Phytochemical Screening for Active Compounds In Pedalium murex L. J. Rec. Res. Sci. Tech. 2010;2(1):110-14.

19. Eggersdorfer M. Terpenes, Ullmann's enclyclopedia of industrial chemistry. Weinheim, Wiley-VCH, 2005;p 26 - 205

20. Costa R, Carlo B, Angela F, Elisa G, Francesco O, Federica S. Antimicrobial activity and chemical composition of Citrus aurantifolia (Christm.) Swingle essential oil from Italian organic crops. Journal of Essential Oil Research. 2014;26(6):400-8.

21. Aelenei P, Miron A, Trifan A, Bujor A, Gille E, and Aprotosoaie AC. Essentia Oils and Their Components as Modulators of Antibiotic Activity against GramNegative Bacteria. Medicines. 2016;3(19):1-34

22. Mariajancyrani J, Chandramohan G, and Ravikumar S. GC-MS Analysis of Terpenes from Hexane Extract of Lantana camara Leaves. Research Journal of Recent Sciences. 2014:3(9):52-5.
23. Miguel MG. Antioxidant and Anti-Inflammatory Activities of Essential Oils: A Short Review. Molecules. 2010;15(12): 9252-9287.

24. Rowe RC. Handbook of Pharmaceutical Excipients Sixth Edition. USA Pharmaceutical Press. 2009;75-76.

25. Manuja R, Sachdeva S, Jain A, Chaudhary J. A Comprehensive Review on Biological activities of p-hydroxy benzoic acid and its derivatives. J. Pharm. Sci. Rev. Res. 2013;22(2): 109-115.

26. Fidrianny I, Rahmawati A, and Hartati R. Comparison profile of different extracts of Averrhoa bilimbi L. In antioxidant properties and phytochemical content Rasayan J. Chem. 2018;11(4):1628-34

27. Abdulkadir A, Zawawi D, and Jahan M. DPPH antioxidant activity, total phenolic and total flavonoid content ofdifferent part of Drumstic tree (Moringa oleifer Lam.). Journal of Chemical and Pharmaceutical Research. 2015:7(4):1423-28.

28. Puangpronpitag D, Areejitranusorn P, Boonsiri P, Suttajit M, Yongvanit $P$ Antioxidant activities of polyphenolic compounds isolated from Antidesma thwaitesianum Müll. Arg. seeds and marcs. Journal of Food Sciences. 2008:73(9):648-53.

29. Dai J, Mumper RJ. Plant Phenolics: Extraction, Analysis and Their Antioxidant and Anticancer Properties. J mol. 2010;15(10):7313-52.

30. Nursid M, Marraskuranto E, Septorini D, and Batubara I. Screening of MarineDerived Fungi Extracts as Antioxidant, Tyrosinase Inhibitor, and Antiglycation. Squalen Bull. of Mar. and Fish. Postharvest and Biotech. 2019:14(1):33-42.

31. Fidrianny I, Harnovi M, Insanu M. Evaluation of Antioxidant Activities from Various Extracts of Sweet Orange Peels using DPPH, FRAP Assay and Correlation with Phenolic, Flavonoid, Carotenaoid Content. Asian J Pharm. Clin Res. 2014;7(3):186-90.

\section{GRAPHICAL ABSTRACT}

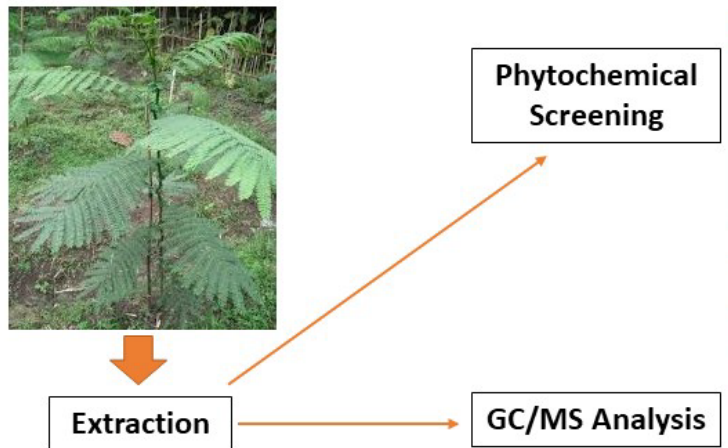

\begin{tabular}{|c|c|c|c|}
\hline № & Chemical Component & Reagent & Results \\
\hline \multirow{3}{*}{4} & Alkaloids & Dragendorff & \\
\hline & & Wagner & - \\
\hline & & Mayer & - \\
\hline 2. & Flavonoids & $\mathrm{HCl}$, Mg powder, amyl alcohol & + \\
\hline 3. & Terpenoids/Steroids & Liebermann-Burchard & + \\
\hline 4. & Phenolic & Methanol and $10 \% \mathrm{NaOH}$ & + \\
\hline 5. & Saponins & Hot water and shaken & + \\
\hline 6. & Tanins & $10 \% \mathrm{FeCl}_{3}$ & + \\
\hline
\end{tabular}

\begin{tabular}{|c|c|c|c|c|}
\hline ames of Components & $\begin{array}{l}\text { Retention Time } \\
\text { (mim) }\end{array}$ & Molecular formula & $\begin{array}{c}\text { Moleculat } \\
\text { Weight } \\
\text { Is/mol| }\end{array}$ & $\begin{array}{l}\text { Peakk Areas } \\
\text { (8) }\end{array}$ \\
\hline & 4.564 & Ciol Has & & \\
\hline & 4.784 & $\mathrm{C}_{\mathrm{CO}} \mathrm{H}$ ia & 136.23 & 4.92 \\
\hline $\begin{array}{l}\text { ellandrene } \\
\text { an-CGenene }\end{array}$ & & $\mathrm{C}_{\mathrm{COH}} \mathrm{ia}$ & 136.23 & 0.63 \\
\hline 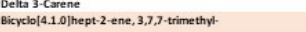 & 5.732 & 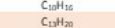 & 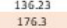 & $\begin{array}{l}10.66 \\
12.00\end{array}$ \\
\hline enzene, methyl|1-methylethyl) - (CAS) Cymol & 5.827 & $c_{2}$ oll $n$ & 134.22 & 2.47 \\
\hline dil-limonene & 5.892 & $\mathrm{C}_{\mathrm{O} O H} \mathrm{H}_{\mathrm{SC}}$ & 136.23 & 12.13 \\
\hline $\begin{array}{l}\text { Eucalyptol } \\
y-\text { Ierpineng }\end{array}$ & 5.960 & $C_{20 H}=0$ & 154.25 & 2.98 \\
\hline $\begin{array}{l}r \text { T-erpinene } \\
\alpha \text {-Terpinolene }\end{array}$ & 6.327 & $C_{\text {COH IIS }}$ & ${ }_{136.23}^{132}$ & 738 \\
\hline 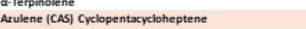 & $\begin{array}{l}6.776 \\
8.267\end{array}$ & 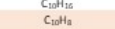 & $\begin{array}{l}136.23 \\
128.17\end{array}$ & $\begin{array}{l}25.85 \\
1.61\end{array}$ \\
\hline $\begin{array}{l}\text { a. Terpineol } \\
\text { 1-Dodecanol|(CAS) n-Dodecanol }\end{array}$ & 8.303 & $\mathrm{C}_{\mathrm{COH}} \mathrm{H}_{\mathrm{H}} \mathrm{O}$ & 154,25 & 2.06 \\
\hline 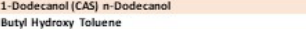 & $\begin{array}{l}12.020 \\
12598\end{array}$ & 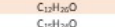 & $\begin{array}{r}186.34 \\
2735\end{array}$ & 1.89 \\
\hline $\begin{array}{l}\text { Buty) Hudroy) loluene } \\
\text { Octadecane (CSS) n-Octadecane }\end{array}$ & $\begin{array}{l}12.598 \\
13507\end{array}$ & 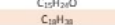 & $\begin{array}{r}222,035 \\
2545\end{array}$ & $\begin{array}{l}1.25 \\
1.32\end{array}$ \\
\hline 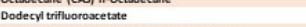 & 14.424 & $C_{n}$ & 282.34 & $\begin{array}{l}1.32 \\
0.67\end{array}$ \\
\hline Oxalic scid, cyclohexylmethyl tridecyl ester & 14,830 & $\mathrm{C}_{2} \mathrm{H}_{\mathrm{WO}} \mathrm{O}$ & 368.5 & 0.86 \\
\hline Methyl myristate & 14.944 & $\mathrm{C}_{1} \mathrm{H}_{1} \mathrm{O}_{2}$ & 242.4 & 1.24 \\
\hline $\begin{array}{l}\text { 9.Heptadecanone } \\
\text { Hexasecanoic scid (CAS) Palmitic sid }\end{array}$ & $\begin{array}{l}16.535 \\
17.374\end{array}$ & 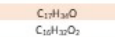 & $\begin{array}{l}254.5 \\
256.42\end{array}$ & $\begin{array}{l}0.59 \\
0.67\end{array}$ \\
\hline
\end{tabular}

\begin{tabular}{|lccc|}
\hline \multicolumn{1}{|c|}{ Extract } & $\begin{array}{c}\text { Concentration } \\
\text { (ppm) }\end{array}$ & $\begin{array}{c}\mathbf{8} \\
\text { Inhibition }\end{array}$ & IC, (ppm) \\
\hline F. & 100 & 58.24 & \\
moluccana & 200 & 62.90 & \\
methanolic & 300 & 70.75 & 12.6 \\
extract & 400 & 75.04 & \\
& 500 & 89.04 & \\
\hline Ascorbic & 1.25 & 14.22 & \\
acid & 2.5 & 21.22 & \\
& 2.75 & 48.24 & 2.17 \\
& 5 & 68.71 & \\
& 6.25 & 84.63 & \\
\hline
\end{tabular}

\section{Summary}

The phytochemical screening of $F$. moluccana methanolic extract showed the presence of phenolics, flavonoids, steroids, terpenoids, saponins, and tannins. The results of GC/MS analysis showed the presence of compounds with antioxidant activity. F. moluccana methanolic extract has the potential as a source of bioactive antioxidant compounds. 


\section{ABOUT AUTHORS}

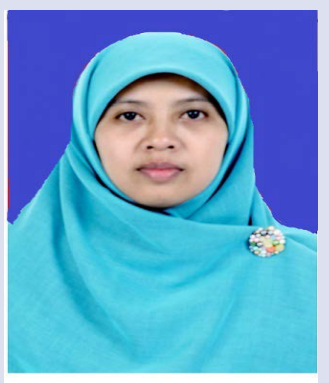

\section{Dr. Alfi Rumidatul}

Lecturer at School of Life Sciences and Technology, Institut Teknologi Bandung, Indonesia, Forestry Technology Research Expertise Group. Research interest: isolation of isolation of plant secondary metabolites and the testing of biological activities to see their potential as antimicrobials, anticancer, antioxidants and chemical processing of non-wood forest products.

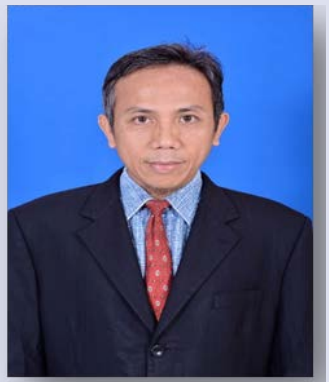

\section{Prof. Dr. I Nyoman Pugeg Aryantha}

Is Professor and Lecturer at School of Life Sciences and Technology, Institut Teknologi Bandung, Indonesia. Microbial Biotechnology Research Expertise Group, Research interest: mycology, plant pathology, microbiology, microbial science and biotechnology, especially eukaryotic microbes, namely fungi.

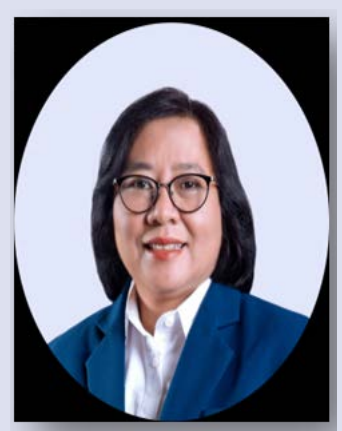

\section{Dr. Endah Sulistyawati}

Lecturer at School of Life Sciences and Technology, Institut Teknologi Bandung, Indonesia, Forestry Technology Research Expertise Group. Research interest: the field of forest ecology, landscape ecology, human ecology, management and conservation of tropical bioresources and environment using various approaches including field survey, computer simulation and remote sensing-based analysis.

Cite this article: Rumidatul A, Aryantha INP, Sulistyawati E. Phytochemicals Screening, GC/MS Characterization, and Antioxidant Activity of Falcataria moluccana Miq. Barneby and J. W. Grimes Methanolic Extract. Pharmacog J. 2021;13(2): 450-5. 